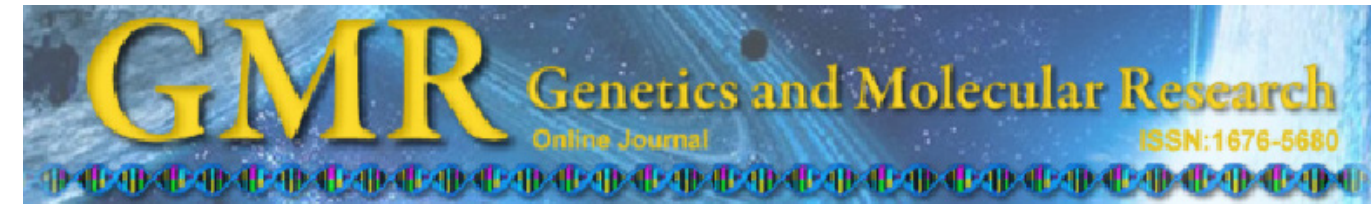

\title{
Identification of sequence-related amplified polymorphism markers linked to the red leaf trait in ornamental kale (Brassica oleracea L. var. acephala)
}

\author{
Y.S. Wang ${ }^{1,2}$, Z.Y. Liu ${ }^{1}$, Y.F. Li ${ }^{3}$, Y. Zhang ${ }^{1}$, X.F. Yang ${ }^{1}$ and H. Feng ${ }^{1}$ \\ ${ }^{1}$ Department of Horticulture, Shenyang Agricultural University, Shenyang, \\ China \\ ${ }^{2}$ Department of Life Sciences, Agriculture and Forestry, Qiqihaer University, \\ Qiqihaer, China \\ ${ }^{3}$ Horticultural Sub-Academy, Heilongjiang Academy of Agricultural Sciences, \\ Harbin, China \\ Corresponding author: H. Feng \\ E-mail: fenghuiaaa@263.net
}

Genet. Mol. Res. 12 (2): 870-877 (2013)

Received March 24, 2012

Accepted December 20, 2012

Published April 2, 2013

DOI http://dx.doi.org/10.4238/2013.April.2.3

\begin{abstract}
Artistic diversiform leaf color is an important agronomic trait that affects the market value of ornamental kale. In the present study, genetic analysis showed that a single-dominant gene, $R e$ (red leaf), determines the red leaf trait in ornamental kale. An $\mathrm{F}_{2}$ population consisting of 500 individuals from the cross of a red leaf double-haploid line 'D05' with a white leaf double-haploid line 'D10' was analyzed for the red leaf trait. By combining bulked segregant analysis and sequence-related amplified polymorphism technology, we identified 3 markers linked to the Re/re locus. A genetic map of the Re locus was constructed using these sequence-related amplified polymorphism markers. Two of the markers, Me8Em4 and Me8Em17, were located on one side of Re/re at distances of 2.2 and $6.4 \mathrm{cM}$, whereas the other marker, Me9Em11, was located on the other side of Re/re at a distance of $3.7 \mathrm{cM}$. These markers could be
\end{abstract}


helpful for the subsequent cloning of the red trait gene and markerassisted selection in ornamental kale breeding programs.

Key words: Ornamental kale; Sequence-related amplified polymorphism; Red leaf

\section{INTRODUCTION}

Ornamental kale (Brassica oleracea L. var. acephala) is a biennial herbaceous cabbage. It is considered more closely related to wild cabbage than to most domesticated forms (Wang et al., 1995). Many varieties of kale are referred to as flowering kales and are grown mainly for their ornamental leaves, which have brilliant white, red, pink, lavender, blue, or violet interiors or rosettes. They are important ornamental foliage crops and are widely used as potted plants or cut flowers (Wang et al., 2011).

Remarkable advancements have been made in the haploid breeding of ornamental kale (Lichter, 1989; Feng et al., 2007), but its unique ornamental characteristics have yet to be investigated in depth. The brunet of the leaf displays dominant inheritance for light color (Gu et al., 2002). Xie (2003) observed that the separation ratios of red and white leaves in the $\mathrm{F}_{2}$ generations of 2 hybridized combinations are close to 3:1 and 15:1. Thus, leaf color is a qualitative trait controlled by 1 or 2 pairs of genes, as combinations of different parents give inconsistent separation ratios.

Molecular markers have advantages over morphological, cytological, and biological markers and have been applied extensively in the life sciences (Fang and Roose, 1997). DNA molecular markers have become effective tools in marker-assisted selection to improve agronomic traits (Lands and Thompson, 1990; Young, 1999; Xiao et al., 2009). However, molecular markers for the leaf color trait in ornamental kale have not been reported until now.

Sequence-related amplified polymorphism (SRAP) is a new and useful molecular marker system for tagging and mapping in B. oleracea (Li and Quiros, 2001). The SRAP system is easy to perform, gives stable and moderate yields and a high proportion of co-dominance, and ultimately simplifies the cloning and sequencing of target segments. The SRAP technique is an effective tool for constructing linkage maps (Yuan et al., 2008), carrying out comparative genomics, and analyzing genetic diversity (Ferriol et al., 2003; Li et al., 2003; Lin et al., 2004) because sequences

are amplified against open reading frames, and sequences near the centromeres and telomeres of genomes are only rarely amplified. The SRAP technique has been applied successfully in studies of sweet potato, rape, and Chinese cabbage (Riaz et al., 2001; Wu et al., 2005; Yu et al., 2009).

The aims of the present study were to determine the genetic mechanism behind the red leaf trait in ornamental kale and identify molecular markers that are tightly linked to this trait by combining a bulked segregant analysis (BSA) (Michelmore et al., 1991) with SRAP marker technology. These data are expected to facilitate marker-assisted selection of the red leaf trait in kale breeding and advance studies for the map-based cloning of the red leaf trait gene.

\section{MATERIAL AND METHODS}

\section{Plant material}

A red leaf, double-haploid line, 'D05', and a white leaf, double-haploid line, 'D10', of 
B. oleracea were used to construct an $\mathrm{F}_{2}$ segregation population (Figure 1). These strains were obtained from isolated microspore cultures of ornamental kale. A cross (D05 x D10) was made to determine the inheritance of the leaf color trait, and $\mathrm{F}_{2}$ and $\mathrm{BC}_{1}$ populations were obtained. The $\mathrm{F}_{2}$ population consisted of 500 plants, which were used for SRAP marker analysis. Plants were grown in a greenhouse under natural sunlight at Shenyang Agricultural University, and leaf color was determined by visual observation during the color development phase.
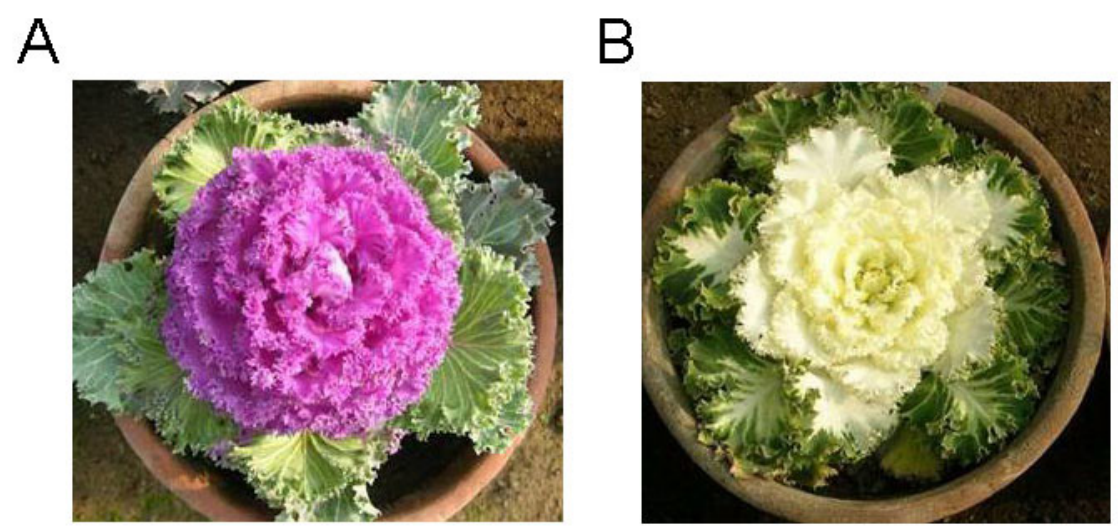

Figure 1. Double-haploid lines of ornamental kale. A. Red leaves (D05). B. White leaves (D10).

\section{DNA extraction and BSA design}

Genomic DNA of the parent plants and the $\mathrm{F}_{2}$ segregating population was extracted from leaves using a cetyltrimethylammonium bromide extraction protocol (Clark, 1997), with minor modifications. The purity and concentration of the DNA were checked on $1 \%(\mathrm{w} / \mathrm{v})$ agarose gels with an ultraviolet spectrophotometer. DNA concentration was adjusted to 50 $\mathrm{ng} / \mu \mathrm{L}$ and stored at $-20^{\circ} \mathrm{C}$ until used. Equal amounts of DNA from 8 red leaf and 8 white leaf plants were selected at random from the $\mathrm{F}_{2}$ population and were pooled to construct 2 DNA bulks for BSA.

\section{SRAP analysis}

A total of 99 SRAP primer combinations from the studies of Li and Quiros (2001), Ferriol et al. (2003), and Li et al. (2003) were used to screen polymorphisms in the 2 parents and 2 DNA bulks. Table 1 shows the SRAP primer sequences used in the present study. All primers were synthesized by TaKaRa Biotechnology Co., Ltd. (Dalian, China). Primers that amplified polymorphic bands in the BSA bulks were tested in the 16 individual plants that made up the 2 bulks and then checked further for their linkage to the red leaf gene in the $\mathrm{F}_{2}$ population (500 individuals). Each polymerase chain reaction (PCR) was performed in a total volume of $10 \mu \mathrm{L}$ made up of $0.8 \mu \mathrm{L} 2.5 \mathrm{mM}$ deoxyribonucleotide triphosphate mix, $1 \mu \mathrm{L} 10 \mathrm{X}$ PCR buffer, $0.2 \mu \mathrm{L} 2.5 \mathrm{U} / \mu \mathrm{L}$ Taq polymerase, $1 \mu \mathrm{L} 3 \mu \mathrm{M} / \mu \mathrm{L}$ forward and reverse primers, 0.5 $\mu \mathrm{L}$ DNA template, and $6.5 \mu \mathrm{L}$ double-distilled $\mathrm{H}_{2} \mathrm{O}$. Each reaction was started at $94^{\circ} \mathrm{C}$ for 3 min, followed by 8 cycles at $94^{\circ} \mathrm{C}$ for $30 \mathrm{~s}, 35^{\circ} \mathrm{C}$ for $30 \mathrm{~s}$, and $72^{\circ} \mathrm{C}$ for $1 \mathrm{~min} ; 35$ cycles at 
$94^{\circ} \mathrm{C}$ for $30 \mathrm{~s}, 50^{\circ} \mathrm{C}$ for $30 \mathrm{~s}$, and $72^{\circ} \mathrm{C}$ for $1 \mathrm{~min}$; and a final extension at $72^{\circ} \mathrm{C}$ for $5 \mathrm{~min}$. PCR products were separated on a $5 \%$ denaturing polyacrylamide gel. After electrophoresis, the gel was stained with $\mathrm{AgNO}_{3}$ in solution (Bassam et al., 1991). SRAP analysis was repeated at least twice for each DNA sample.

\begin{tabular}{llcl}
\multicolumn{2}{l}{ Table 1. Primer sequences of polymorphic SRAP markers used in this study. } & \\
\hline Forward primer name & Sequence (5'-3') & Reverse primer name & Sequence (5'-3') \\
\hline Mel & TCAGTCCAAACCGGATA & Em1 & GACTGCGTACGAATTAAT \\
Me2 & TGAGTCCAAACCGGAGC & Em2 & GACTGCGTACGAATTTGC \\
Me3 & TGAGTCCAAACCGGAT & Em3 & GACTGCGTACGAATTGAC \\
Me4 & TGAGTCCAAACCGGACC & Em4 & GACTGCGTACGAATTTAA \\
Me5 & TGAGTCCAAACCGGAAG & Em5 & GACTGCGTACGAATTAAC \\
Me6 & TGAGTCCAAACCGGTAA & Em6 & GACTGCGTACGAATTGCA \\
Me7 & TGAGTCCAAACCGGTAG & Em7 & GACTGCGTACGAATTCAA \\
Me8 & TGAGTCCAAACCGGAAC & Em8 & GACTGCGTACGAATTCTG \\
Me9 & TGAGTCCAAACCGGAGT & Em9 & GACTGCGTACGAATTCGA \\
& & Em10 & GACTGCGTACGAATTCAG \\
& & Em11 & GACTGCGTACGAATTCCA \\
\hline
\end{tabular}

\section{Linkage analysis and marker nomenclature}

Linkage analysis was carried out using Join Map 3.0 (Van Ooijen et al., 2001), and the linkage group was drawn using MapChart (Voorrips, 2002). Recombination percentages were converted to genetic distances using the Kosambi mapping function (Kosambi, 1944). The polymorphic markers were named according to their corresponding primer combination codes.

\section{RESULTS}

\section{Genetic analysis of the red leaf color trait in kale}

The results of the genetic analysis are shown in Table 2. All 30 plants obtained from the cross (D05 x D10) had red leaves, indicating that the red leaf trait was dominant. Chi-square tests of the cross (D05 x D10) confirmed a ratio of 3:1 (red leaf:white leaf) in the $\mathrm{F}_{2}$ population, and 1:1 (red leaf:white leaf) in the $\mathrm{BC}_{1}$ backcross population (using the white leaf line as the recurrent parent). These results indicate that a single-dominant gene controls the red leaf trait. The dominant and recessive alleles of this gene are herein referred to as Re/re.

\begin{tabular}{|c|c|c|c|c|c|}
\hline \multirow[t]{2}{*}{ Population } & \multirow[t]{2}{*}{ Total No. of individuals } & \multicolumn{2}{|c|}{ D05 x D10 } & \multirow[t]{2}{*}{ Expected ratio } & \multirow[t]{2}{*}{$\chi^{2}$} \\
\hline & & No. of red leaf plants & No. of white leaf plants & & \\
\hline$F_{1}$ & 30 & 30 & & & \\
\hline $\mathrm{F}_{2}^{1}$ & 500 & 376 & 124 & $3: 1$ & 0.011 \\
\hline $\mathrm{BC}_{1}^{2}$ & 123 & 61 & 62 & $1: 1$ & 0.008 \\
\hline
\end{tabular}




\section{Detection of genomic DNA purity and integrity}

Genomic DNA from leaves was extracted, and the integrity of DNA was deemed acceptable with $1 \%$ agarose gel electrophoresis, as the DNA bands were distinct and showed no dispersed appearance (Figure 2). The ratios of optical density $(\mathrm{OD})_{260}: \mathrm{OD}_{280}$ were always between 1.819 and 1.954 .

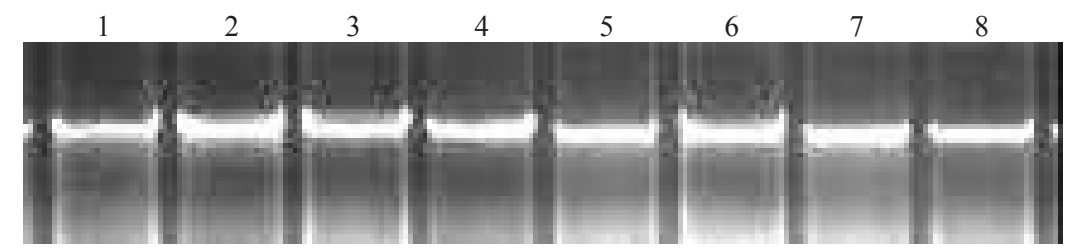

Figure 2. Electrophoresis of genomic DNA. Lanes 1 to $8=$ individuals selected randomly from $\mathrm{F}_{2}$ population.

\section{Detection of SRAP markers linked to the Re/re locus}

To identify markers linked to the Re/re gene, we used 99 SRAP primers to observe polymorphism. Of these, 41 primer combinations $(41.4 \%)$ were polymorphic in both parent plants (D05 and D10). After further testing with the 2 DNA bulks and 16 individuals that made up these 2 DNA bulks, 3 SRAP primer combinations (Me8Em4, Me8Em17, and Me9Em11) were found to exhibit polymorphic bands between the 2 bulks and 16 individuals. We used these 3 markers to test the recombination ratio in the 124 individuals with the recessive $r e$ allele. This analysis showed that the numbers of recombinant plants in this population were 10 , 13 , and 11 , respectively, giving recombination ratios of $4.0,5.2$, and $4.4 \%$, respectively. The amplification results of the 3 primers in the recessive plants are shown in Figure 3.

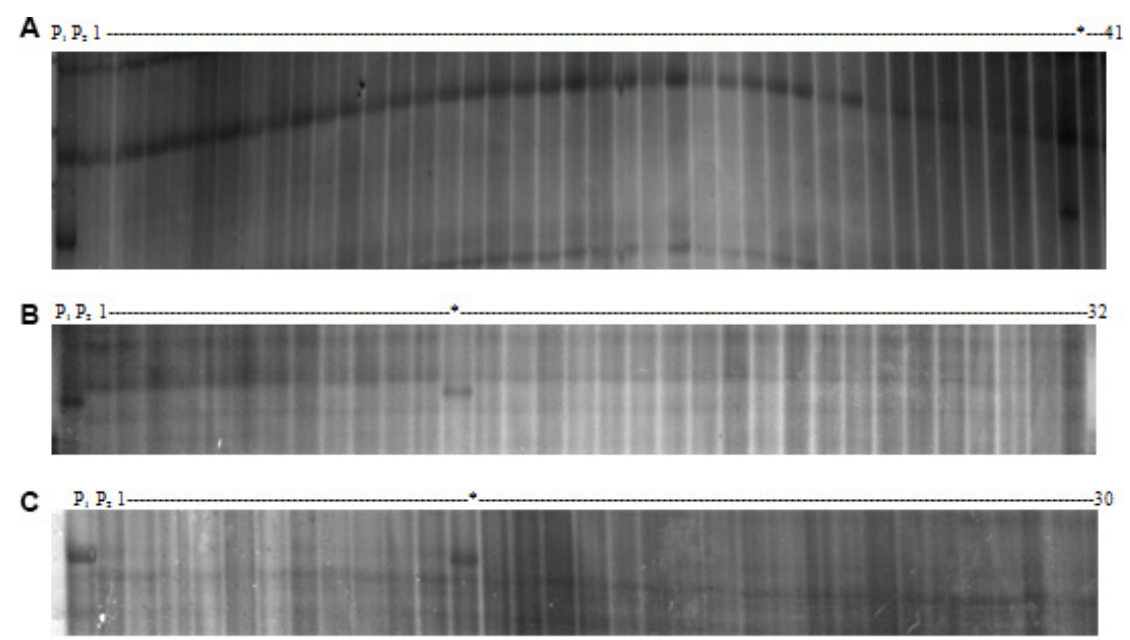

Figure 3. A. Amplification of Me8Em4 in parental lines and white leaf individuals. B. Amplification of Me8Em17 in parental lines and white leaf individuals. C. Amplification of Me9Em11 in parental lines and white leaf individuals. Lane $P_{1}=$ D05; lane $P_{2}=\mathrm{D} 10$; lanes 1 to $41(\mathrm{~A})$; lanes 1 to $32(\mathrm{~B})$; lanes 1 to $30(\mathrm{C})=$ all white leaf individuals; $(*)=$ recombinants. 


\section{Linkage group construction of the Re/re locus}

The preliminary linkage analysis was performed using Join Map 3.0, revealing that the 3 linked SRAP markers flanking the Re/re locus were Me8Em4 at $2.2 \mathrm{cM}, \mathrm{Me} 8 \mathrm{Em} 17$ at $6.4 \mathrm{cM}$, and Me9Em11 at $3.7 \mathrm{cM}$. The linkage group constructed with the markers linked to the Re/re locus is shown in Figure 4. Two markers - Me8Em4 and Me8Em17 - are located on one side of the Re/re locus, whereas the other marker (Me9Em11) is on the other side of this locus.

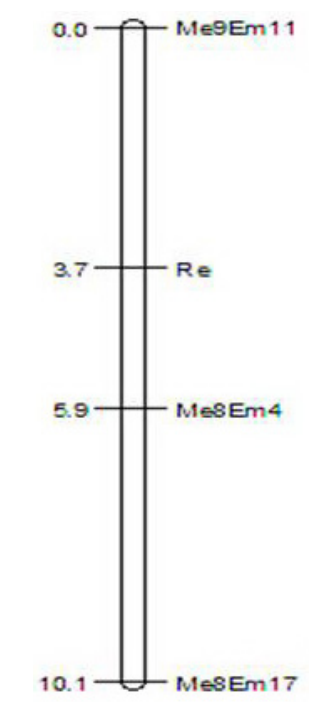

Figure 4. Genetic linkage map of the $R e$ locus generated in the recombinant population (500 individuals) from the cross (D05 x D10).

\section{DISCUSSION}

Ornamental kale displays a range of leaf colors and shapes (Zhao et al., 2009). This kale has a longer ornamental period owing to its tolerance of cold temperatures, and it is also amenable to large-scale cultivation (Zhao et al., 2009). Because of these desirable characteristics, the plant is used widely for landscaping in cities and has become an important landscape plant during cold seasons. In the present study, of 500 individuals in the $\mathrm{F}_{2}$ population, 124 individuals had white leaves, giving a segregation ratio of 3:1 (chi-square $=0.011<$ chisquare $\left._{0.05}=3.841=3.841\right)$. This segregation ratio confirmed that the red leaf trait is controlled by a single-dominant gene (Gu et al., 2002).

SRAP has been used widely in genetic studies of plant species including $B$. oleracea (Li et al., 2003), Cucurbita pepo (Ferriol et al., 2003), and Brassica rapa (Rahman et al., 2007). Compared with other randomly amplified markers, SRAP markers are distributed more evenly throughout the whole genome. Owing to the random combination of forward and reverse primers, SRAP markers may reduce the cost of primer synthesis and greatly improve efficiency by using only a small amount of primer to generate a large number of combinations (Liu et al., 2009). Both the polymorphism ratio and polymorphic fragment number of each 
primer pair of SRAP markers are greater than those yielded by random-amplified polymorphic DNA (RAPD). SRAP has the same operation convenience as RAPD but shows improved stability over RAPD (Liu et al., 2004). In addition, SRAP markers require no complex mix of enzymes for cutting, connection, and pre-amplification compared with that needed for amplified fragment length polymorphism markers, which makes SRAP a more effective molecular marker system for genome studies (Xu and Zhao, 2009).

Of the 99 SRAP primer combinations tested in this study, 41 pairs (41.4\%) were polymorphic between the 2 parents. BSA involves the mixing DNA of plants from a population with the same phenotype, which creates 2 gene bulks with the same genetic background except for the target gene loci (Chen et al., 2007). We screened polymorphisms of 99 SRAP pairs in the 2 parent plants and 2 DNA bulks by combining BSA and SRAP molecular marker approaches, and this technique identified 3 SRAP markers linked to the red leaf trait. Specifically, these markers were Me8Em4, Me8Em17, and Me9Em11, found at genetic distances of $2.2,6.4$, and $3.7 \mathrm{cM}$, respectively.

Fine mapping of a gene is essential for map-based cloning (Tanksley et al., 1995), and some genes of carotenoid mutants have been isolated using a map-based cloning technique (Ronen et al., 2000; Isaacson et al., 2002). Thus, the information presented in this paper may be useful for further fine-mapping studies and ultimately for map-based cloning of $R e$. We are currently preparing to fine map $R e$ after the construction of a large-scale segregating population.

\section{ACKNOWLEDGMENTS}

Research supported by grants from the National Natural Science Foundation of China (\#31071792) and the Specialized Research Fund for the Doctoral Program of Higher Education (\#20122103110006). We thank the present and past colleagues in our laboratory for constructive discussions.

\section{REFERENCES}

Bassam BJ, Caetano-Anolles G and Gresshoff PM (1991). Fast and sensitive silver staining of DNA in polyacrylamide gels. Anal. Biochem. 196: 80-83.

Chen F, Zhang JF, Chen S, Gu H, et al. (2007). SRAP markers linked to recessive genic male sterile gene in rapeseed (Brassica napus L.). Jiangsu J. Agric. Sci. 23: 283-284.

Clark MS (1997). Plant Molecular Biology: A Laboratory Manual. Springer, Berlin.

Fang DQ and Roose ML (1997). Identification of closely related citrus cultivars with inter-simple sequence repeat markers. Theor. Appl. Genet. 95: 408-471.

Feng H, Jiang FY, Feng JY and Wang CN (2007). Establishment and application of the system for isolated microspore culture in Kale (Brassica oleracea L. var. acephala DC.). Acta. Hort. 34: 1019-1022.

Ferriol M, Pico B and Nuez F (2003). Genetic diversity of a germplasm collection of Cucurbita pepo using SRAP and AFLP markers. Theor. Appl. Genet. 107: 271-282.

$\mathrm{Gu}$ WH, Zheng HJ, Zhang Y and Liu ZY (2002). A preliminary study on selection and breeding of new lines and main genetic characteristics of ornamental kale. J. Shanghai Jiaotong Univ. 20: 129-132.

Isaacson T, Ronen G, Zamir D and Hirschberg J (2002). Cloning of tangerine from tomato reveals a carotenoid isomerase essential for the production of beta-carotene and xanthophylls in plants. Plant Cell 14: 333-342.

Kosambi DD (1944). The estimation of map distance from recombination values. Ann. Eugen. 12: 172-175.

Lands R and Thompson R (1990). Efficiency of marker-assisted selection in the improvement of quantitative traits. Genetics 124: 743-756.

Li G and Quiros CF (2001). Sequence-related amplified polymorphism (SRAP), a new marker system based on a simple PCR reaction: its application to mapping and gene tagging in Brassica. Theor. Appl. Genet. 103: 455-461. 
Li G, Gao M, Yang B and Quiros CF (2003). Gene for gene alignment between the Brassica and Arabidopsis genomes by direct transcriptome mapping. Theor. Appl. Genet. 107: 168-180.

Lichter R (1989). Efficient yield of embryods by culture of isolated microspores of different Brassicaceae species. Plant Breed. 103: 119-123.

Lin ZX, Zhang XL and Nie YC (2004). Evaluation of application of a new molecular marker SRAP on analysis of $\mathrm{F}_{2}$ segregation population and genetic diversity in cotton. Yi Chuan Xue Bao 31: 622-626.

Liu LJ, Liu ZC, Chen HR and Luo LJ (2009). SRAP marker technique and its application in genetic diversity analyses of vegetable crops. Chin. Agric. Sci. Bull. 25: 43-48.

Liu LW, Gong YQ, Huang H and Zhu XW (2004). Novel molecular marker systems - SRAP and TRAP and their application. Yi Chuan 26: 777-781.

Michelmore RW, Paran I and Kesseli RV (1991). Identification of markers linked to disease-resistance genes by bulked segregant analysis: a rapid method to detect markers in specific genomic regions by using segregating populations. Proc. Natl. Acad. Sci. U. S. A. 88: 9828-9832.

Rahman M, McVetty PB and Li G (2007). Development of SRAP, SNP and multiplexed SCAR molecular markers for the major seed coat color gene in Brassica rapa L. Theor. Appl. Genet. 115: 1101-1107.

Riaz A, Li G, Quresh Z, Swati MS, et al. (2001). Genetic diversity of oil seed Brassica napus inbred lines based on sequence-related amplified polymorphism and its relation to hybrid performance. Plant Breed. 120: 411-415.

Ronen G, Carmel-Goren L, Zamir D and Hirschberg J (2000). An alternative pathway to $\beta$-carotene formation in plant chromoplasts discovered by map-based cloning of Beta and old-gold color mutations in tomato. Proc. Natl. Acad. Sci. U. S. A. 97: 11102-11107.

Tanksley SD, Ganal MW and Martin GB (1995). Chromosome landing: a paradigm for map-based gene cloning in plants with large genomes. Trends Genet. 11: 63-68.

Van Ooijen JW and Voorrips RE (2001). JoinMap ${ }^{\circledR}$ 3.0, Software for the Calculation of Genetic Linkage Maps. Plant Research International, Wageningen, The Netherlands.

Voorrips RE (2002). MapChart: software for the graphical presentation of linkage maps and QTLs. J. Hered. 93: 77-78.

Wang HM, Du GC, Jia CY, Tan XW, et al. (1995). In vitro propagation of ornamental kale (Brassica oleracea var. acephala f. tricolor hort.). Acta. Agric. Boreal.-Sin. 10: 64-69.

Wang YS, Tong Y, Li YF, Zhang Y, et al. (2011). High frequency plant regeneration from microspore-derived embryos of ornamental kale (Brassica oleracea L. var. acephala). Sci. Hortic. 130: 296-302.

Wu J, Tan WF, He JR, Pu ZG, et al. (2005). Construct on of SRAP linkage map and QTL mapping for starch content in sweet potato. Mol. Plant Breed. 3: 841-845.

Xiao JP, Chen LG, Xie M, Liu HL, et al. (2009). Identification of AFLP fragments linked to seedlessness in Ponkan mandarin (Citrus reticulata Blanco) and conversion to SCAR markers. Sci. Hortic. 121: 505-510.

Xie LN (2003). Genetic Analysis of Leaf Color and Shape and Mechanism of Self-Incompatibility of Brassica oleracea var. acephala. Master's thesis, Northeast Forestry University, Harbin.

$\mathrm{Xu}$ C and Zhao BH (2009). The development and application of SRAP molecular markers. Life Sci. Instrum. 7: 24-27.

Young ND (1999). A cautiously optimistic vision for marker-assisted breeding. Mol. Breed. 5: 505-510.

Yu YJ, Zhang YW and Zhang DS (2009). SRAP markers linked to purple trait in Chinese cabbage. Mol. Plant Breed. 7: 573-578.

Yuan XJ, Pan JS, Cai R, Guan Y, et al. (2008). Genetic mapping and QTL analysis of fruit and flower related traits in cucumber (Cucumis sativus L.) using recombinant inbred lines. Euphytica 164: 473-491.

Zhao XS, Li MY, Zhang WL and Liu F (2009). Establishment of high adventitious shoot regeneration system of ornamental kale. Genom. Appl. Biol. 28: 141-148. 